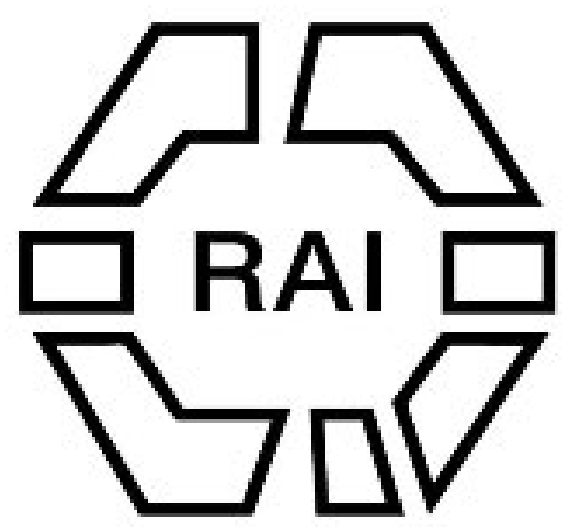

On the Evolution of the Earliest Palaeoliths from the Rostro-Carinate Implements.

Author(s): J. Reid Moir

Source: The Journal of the Royal Anthropological Institute of Great Britain and Ireland, Vol. 46 (Jan. - Jun., 1916), pp. 197-220

Published by: Royal Anthropological Institute of Great Britain and Ireland

Stable URL: http://www.jstor.org/stable/2843472

Accessed: 20/12/2014 20:33

Your use of the JSTOR archive indicates your acceptance of the Terms \& Conditions of Use, available at http://www.jstor.org/page/info/about/policies/terms.jsp

JSTOR is a not-for-profit service that helps scholars, researchers, and students discover, use, and build upon a wide range of content in a trusted digital archive. We use information technology and tools to increase productivity and facilitate new forms of scholarship. For more information about JSTOR, please contact support@jstor.org. 


\title{
ON THE EVOLUTION OF THE EARLIEST PALAOLITHS FROM THE ROSTRO-CARINATE IMPLEMENTS.
}

\author{
By J. REID MOIR.
}

IN the present paper the author proposes to describe and figure a series of ten flint implements derived from-

(a) The detritus-bed below the Red Crag of Suffulk,

(b) The stone-bed below the Norwich Crag,

(c) The Middle Glacial Gravel of Suffolk, and

(d) River Gravels situated in the Thames Valley and a.t Warren Hill in Suffolk.

It is proposed also to demonstrate that these ten implements exhibit a gradual evolution from the most primitive form of the rostro-carinate to the more highly developed pointed implement of the earliest Chelles type.

It has generally been supposed that the flint implements of man found in 1909 in the detritus-bed below the Red Crag of Suffolk bear no cultural relationship to the later palæolithic implements. It has also been generally held that these two series of implements-the sub-crag specimens and the palæoliths--were separated by a great gap of time during which vast changes in the configuration of the surface of the land tuok place. The latter view, involving as it does many complex geological questions, the author, though inclined to look upon it as unsatisfactory, does not feel himself to be competent to discuss with any profit. ${ }^{1}$ Regarding the former, he is of the opinion that the series of flint implements which forms the subject matter of this paper, affords evidence tending to show that in the case of the sub-crag rostro-carinates and the pointed implements of the earliest Chelles type there is a distinct cultural relationship. If this evidence is found to be sound, it follows that, the whole of the sub-crag "culture" is related to that pertaining to the early Chelles phase. To arrive at a proper understanding of the question presently to be discussed, viz., the relationship of the most primitive rostro-carinates

1 It appears that M. Commont plaçs the earliest palæolithic implements at about the beginning of the Pleistocene period. (Les hommes contemporains du Renne, pp. 5 and 6.) 
to the pointed implements of the earliest Chelles type, it appears to be necessary, first of all, to grasp clearly what is implied by the term "rostro-carinate" as. applied to a humanly fashioned flint. A rostro-carinate is an implement with broad posterior region, narrowed anteriorly to a quasi-vertical cutting edge. This anterior narrow edge is strongly curved and gives the implement the form of the beak of an accipitrine bird. The form of this region of the implement may also be compared to that of the prow of a boat (the boat being turned keel upwards).

If the implement is held with the prow or beak to the front, there are observed an upper or dorsal plane, a lower or ventral plane, a right lateral and left lateral surface, a posterior surface or stern (P in Fig. 1), and an anterior surface, narrowed to the form of a keel and ending in a beak (hence the term "rostro-carinate"): as a consequence of the oblique direction and convergence of the lateral surfaces, which approach one another so as to leave only a narrow keel-like ridge between them. ${ }^{1}$

$(a)$

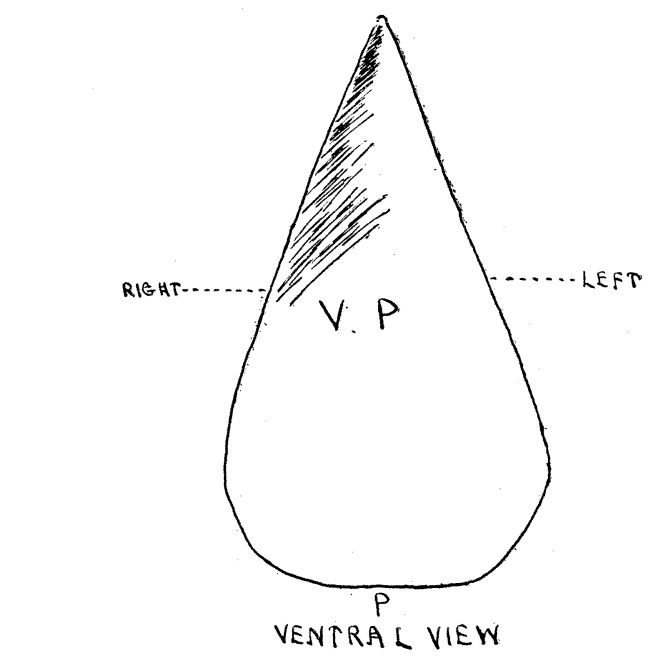

(b)

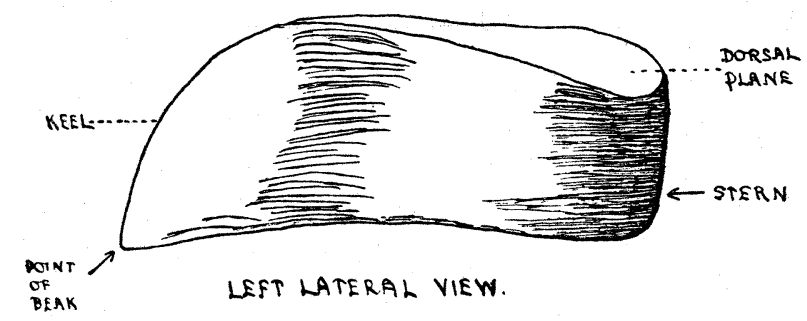

FIG. 1. $(c)$

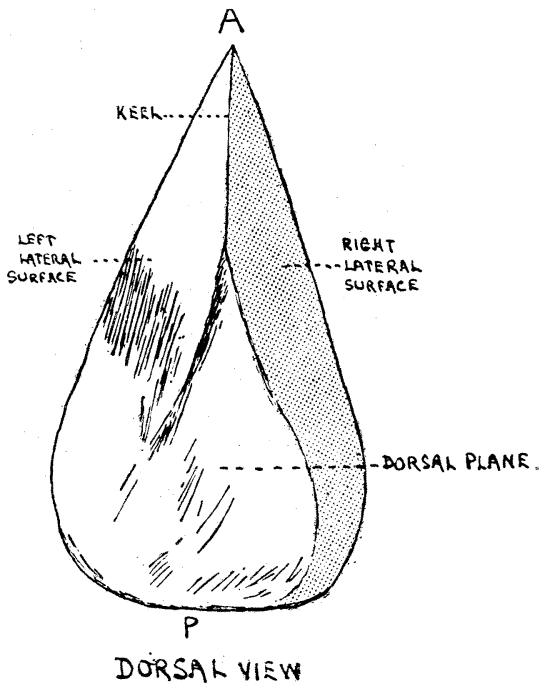

1 This description is copied from that given in Sir Ray Lankester's Memoir (Phil. Trans., Roy. Soc., May, 1912). The drawing of an ideal rostro-carinate which accompanies this description is also taken from the same publication. In all text figures D.P. $=$ dorsal plane. V.P. $=$ ventral plane. Ant. $=$ anterior. Post. $=$ posterior. 
The method of making a rostro-carinate flint implement is as follows. A nodule of flint, preferably of a flattened potato shape, is selected and a flake detached from one end in such a manner as to produce the ventral plane (Fig. 2, $\alpha$ ). Then having by this means produced the necessary flat striking surface, blows are delivered on both sides of this surface and flakes removed to form the typical "keel" (Fig. 2, b). It is necessary to hold the flint which is being flaked, in a particular manner, otherwise the flakes will not be removed at the required angle, and no "keel" will be formed.

The overhanging appearance of the anterior narrow edge of the "keel" which gives to it a likeness to the beak of an accipitrine bird, can be produced by removing the primary flake forming the ventral plane of a markedly concave shape (Fig. 2,c).

(a)

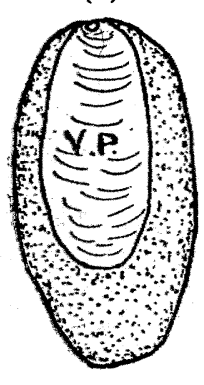

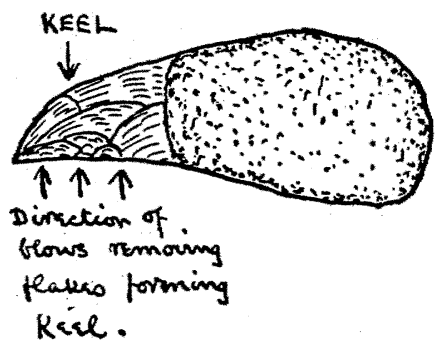

(c)

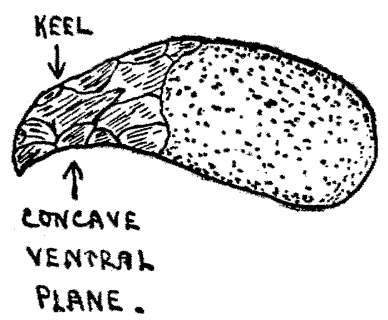

FIG. 2.

It is sometimes found to be necessary to remove flakes by blows delivered upon the dorsal as well as on the ventral surface, in order to produce the desired form of implement, and an examination of the sub-crag specimens shows that their makers occasionally adopted this method.

Having now ascertained the exact form of a rostro-carinate flint implement it is possible to proceed to examine the ten specimens, which it is the main intention of this paper to describe, and to see wherein they approximate to this form or diverge from it. The specimens will be described in an order based upon what the author regards as their state of evolution; the most primitive implement will be dealt with first, and the most highly evolved last.

In this description, no account will be given of the patination, condition, etc., of the various specimens. This inquiry deals solely with their form.

\section{No. 1, Fig. 3.}

Recovered from the detritus-bed below shelly Red Crag at Thorington Hall, Wherstead, near Ipswich.

This specimen, which exhibits the various characteristics of a rostro-carinate (as outlined above), is regarded by the author as representing the most simple and

voL. XLVI. 
primitive type of this implement yet found below the Red Crag. A flattened nodule of flint, concave on its upper surface, convex upon its lower, with rounded sides, has been flaked at one end into the form of a beak.

$\$ a)$

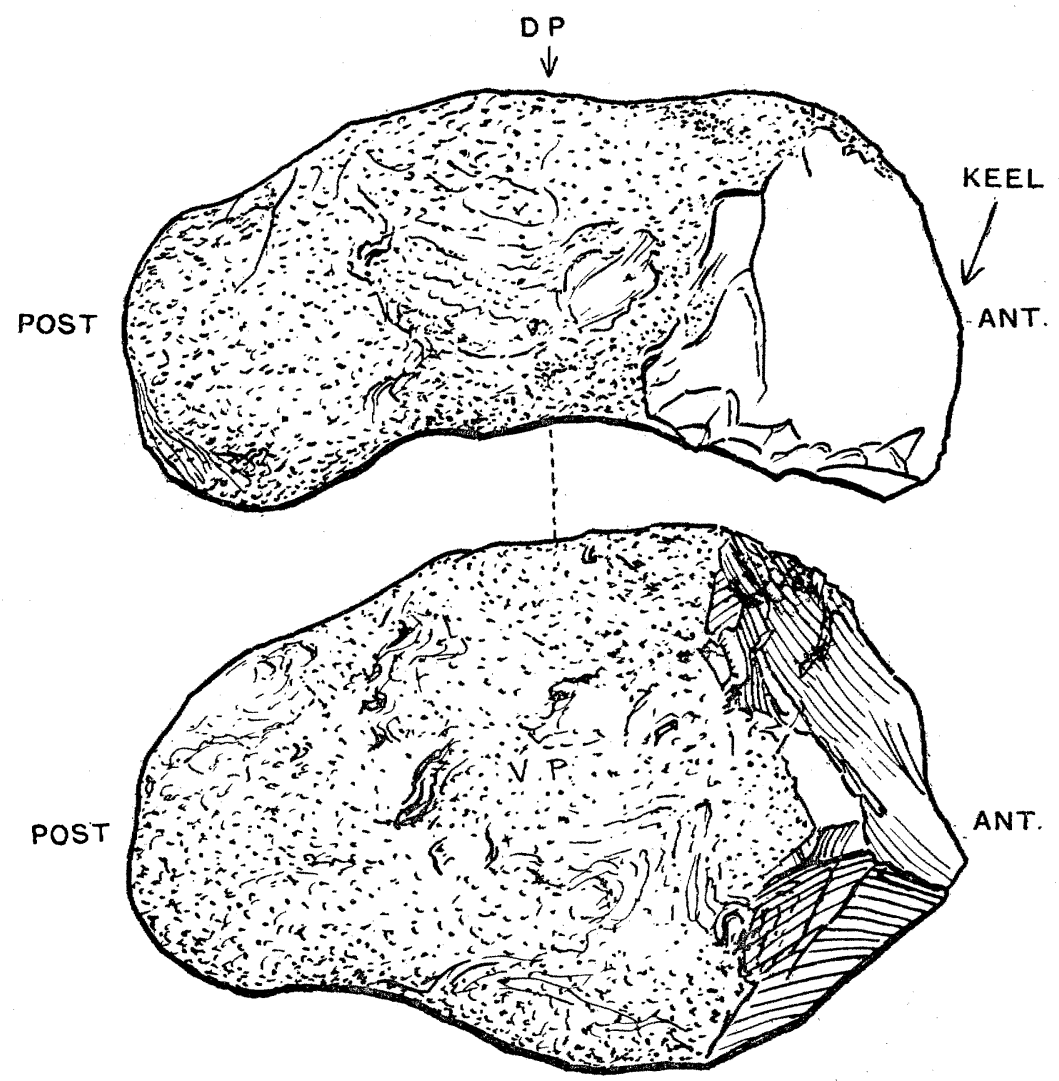

FiG. 3.-VIEW OF (a) RIGHT LATERAL SURFACE ; $(b)$ VENTRAL PLANE OF MOST PRIMITIVE TYPE OF ROSTRO-CARINATE IMPLEMENT. (2 NATURAL.)

The dorsal and ventral planes, the right and left lateral surfaces and the stern, are all represented by unflaked cortex, which in the case of the ventral plane extends to the very point of the beak. This specimen, then, may be regarded as a true rostro-carinate, but of a very simple and primitive type.

\section{No. 2, Fig. 4.}

Recovered from the detritus-bed below the decalcified Red Crag in the brickfield of Messrs. A. Bolton \& Co., Ltd., Henley Road, Ipswich. This specimen, which is made from a cylindrical nodule of flint, exhibits the usual characteristics of a rostro-carinate implement. The dorsal plane and the right and left lateral surfaces are represented by unflaked cortex. The stern has had one or two flakes removed, while the opposite end of the nodule has been fashioned into the form of a beak. 
The ventral plane in this specimen is largely composed of unflaked cortex, but immediately under the point of the beak a flake has been removed forming a flat surface. This specimen may be regarded as a true rostro-carinate which exhibits an advance on implement' No. 1 (Fig. 3), in that the first attempt to produce a ventral plane by flaking is observable.

$(\alpha)$

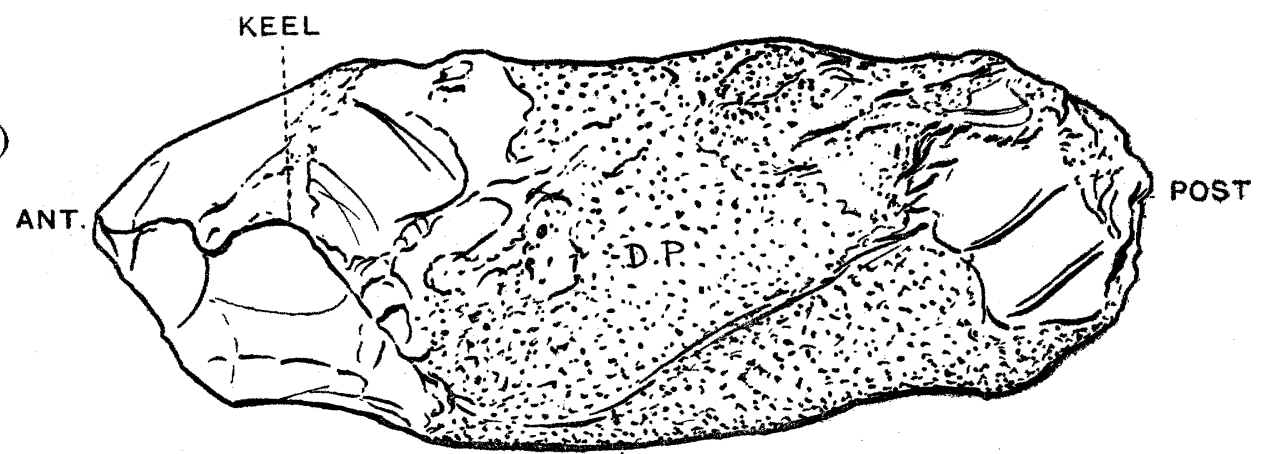

(b)

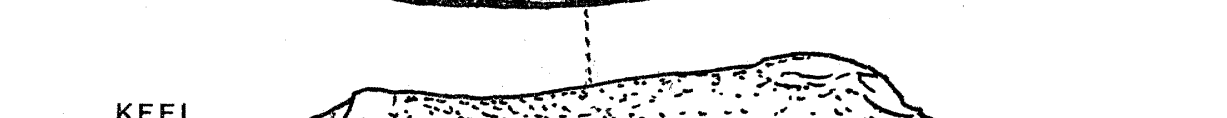

(c)
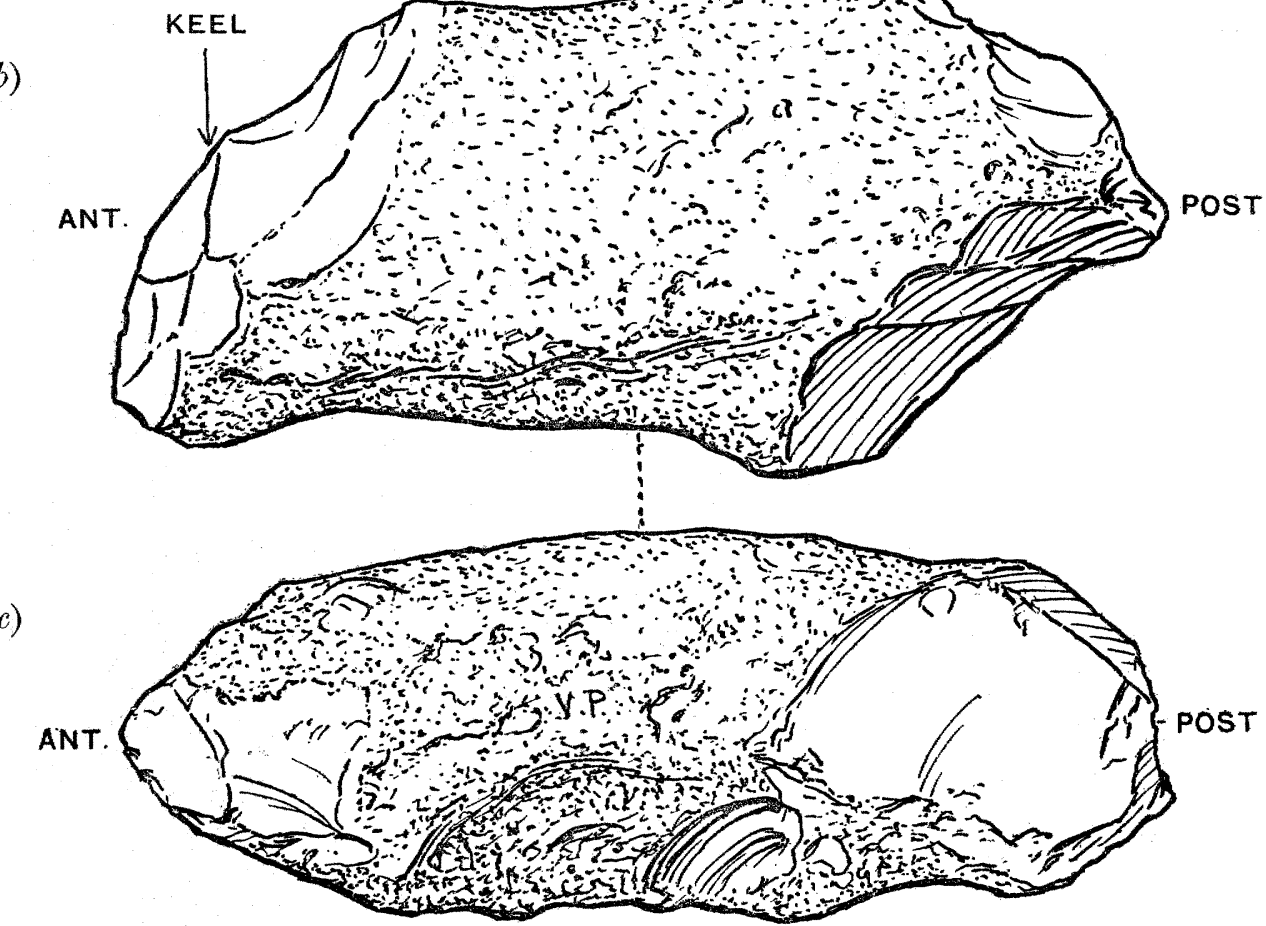

Fig. 4. - VIEW OF ( $a$ ) DORSAL SURFACE ; $(b)$ LEFT LATERAL SURFACE OF ROSTRO-CARINATE IMPLEMENT SHOWING SECOND STAGE OF EVOLUTION; $(c)$ VENTRAL SURFACE. ( $\frac{2}{3}$ NATURAL.) 


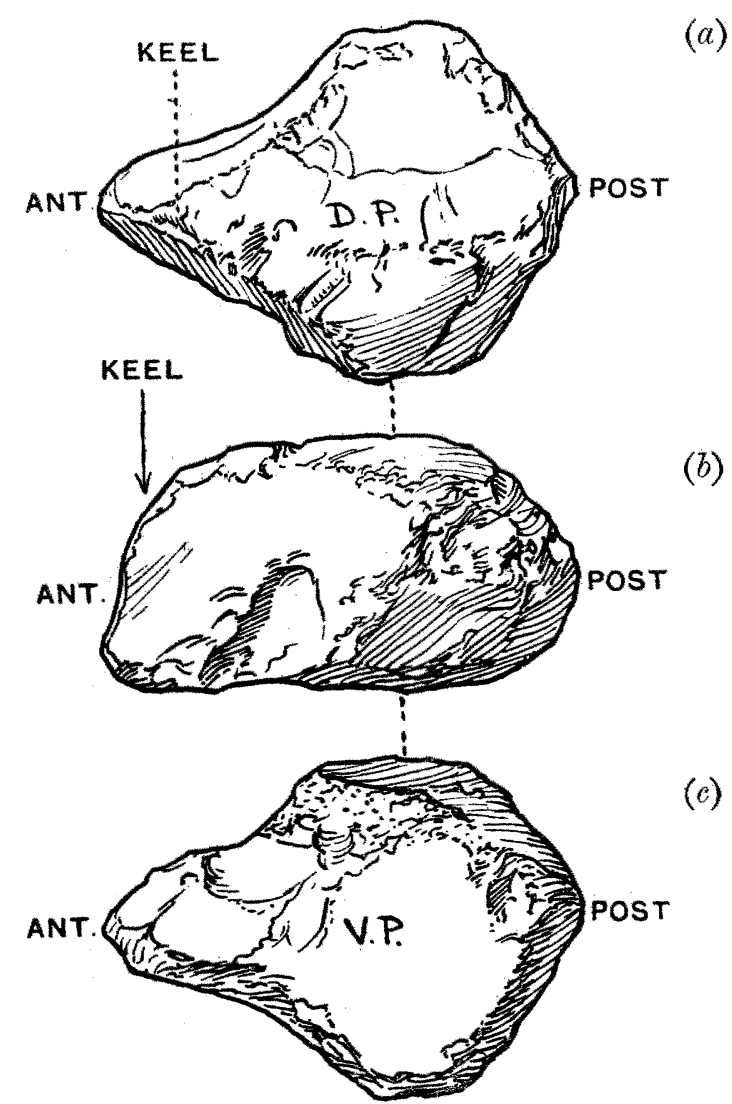

FIG. 5.-VIEW OF (a) DORSAL SURFACE ; $(b)$ LEFT LATERAL SURFACE OF ROSTRO-CARINATE IMPLEMENT SHOWING THIRD STAGE OF EVOLUTION; $(c)$ VENTRAL SURFACE. (2 NATURAL.)

\section{No. 3, Fig. 5.}

Recovered from the detritus-bed below the decalcified Red Crag in the brickfield of Messrs. A. Bolton \& Co., Ltd., Henley Road, Ipswich. This specimen exhibits the usual characteristics of a rostro-carinate implement. The dorsal plane and the stern are composed of unflaked cortex. The right and left lateral surfaces are represented by cortex, while the anterior portion has been flaked into the form of a beak. The ventral surface, in this specimen, exhibits no cortex, but has been formed by flaking. This implement is regarded as a true rostro-carinate exhibiting an advance on specimen 2 , in that the whole of the ventral surface has been formed by blows removing flakes.

$$
\text { No. 4, Fig. } 6 .
$$

Found in a pit at Whitlingham near Norwich, by Mr. W. G. Clarke, in April, 1911. This specimen, which is now housed in the British Museum (Bloomsbury), has been described by E. Ray Lankester (Description of the Test specimen of the rostro-carinate industry found beneath the Norwich Crag, Royal Anthropological Institute, Occasional Papers, No. 4). 
This specimen, which is entirely "flaked out," that is, has no portion of the original cortex of the flint left upon it, shows all the characteristics of the rostrocarinate type. The ventral surface has been formed by one blow, while the dorsal

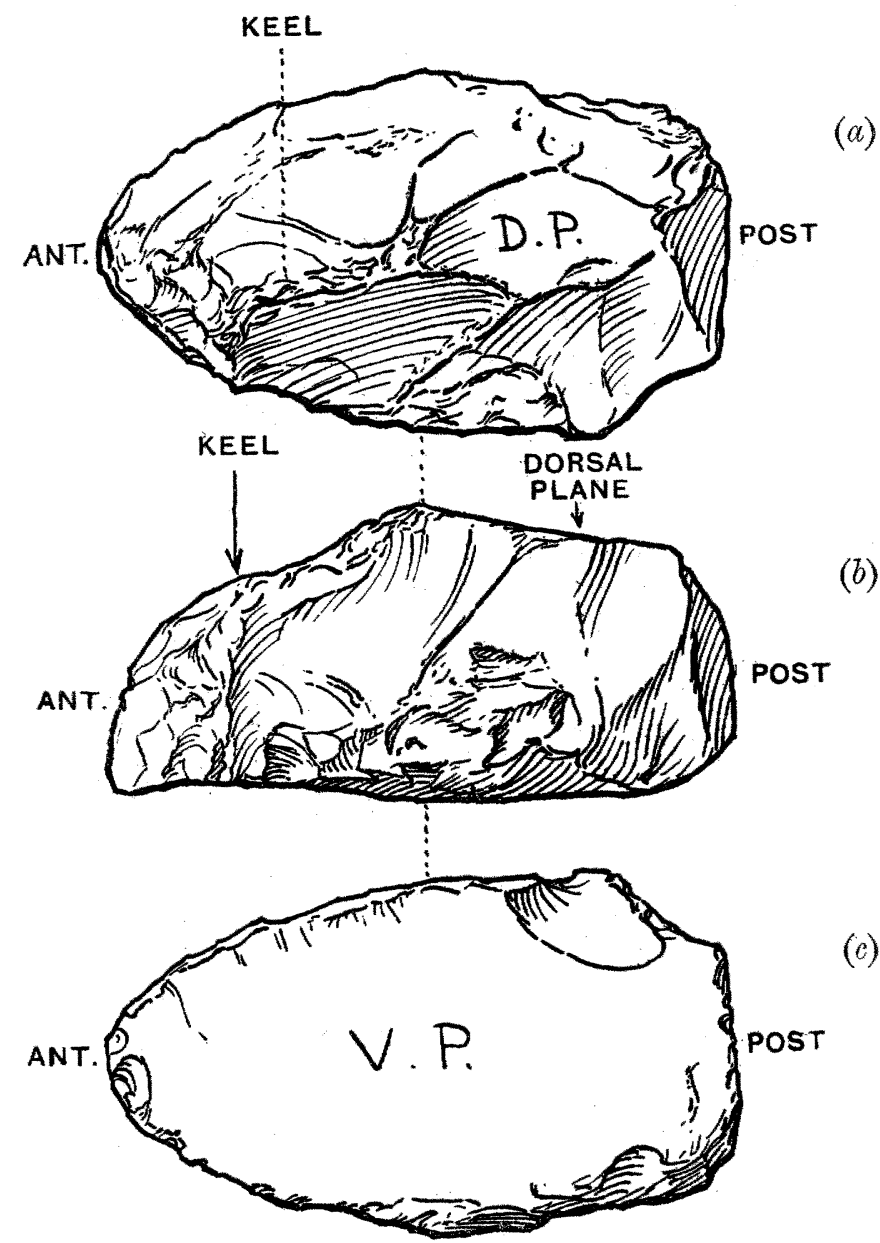

FIG. 6.-VIEW OF ( $a$ ) DORSAL SURFACE; $(b)$ LEFT LATERAL SURFACE OF ROSTRO-CARINATE IMPLEMENT SHOWING FOURTH STAGE OF EVOLUTION ; $(c)$ VENTRAL SURFACE. (壬 NATURAL.)

platform is flat and perfectly developed. This implement shows an advance on specimen 3 (Fig. 5), in that both the dorsal and ventral planes are represented by flaked areas, and by the greater symmetry of its outline. ${ }^{1}$

\section{No. 5, Fig. 7 .}

Recovered from the Middle Glacial Gravel in a pit in the occupation of Messrs. A. Bolton \& Co،, Ltd., Henley Road, Ipswich. This specimen shows all the

1 The author is indebted to Sir Hercules Read of the British Museum for permission to figure this specimen. 
characteristics of a true rostro-carinate implement, but is more shapely and "delicate" in its outline than the implements hitherto described. It shows a small amount of cortex at the posterior region, but is otherwise entirely "flaked out." It differs

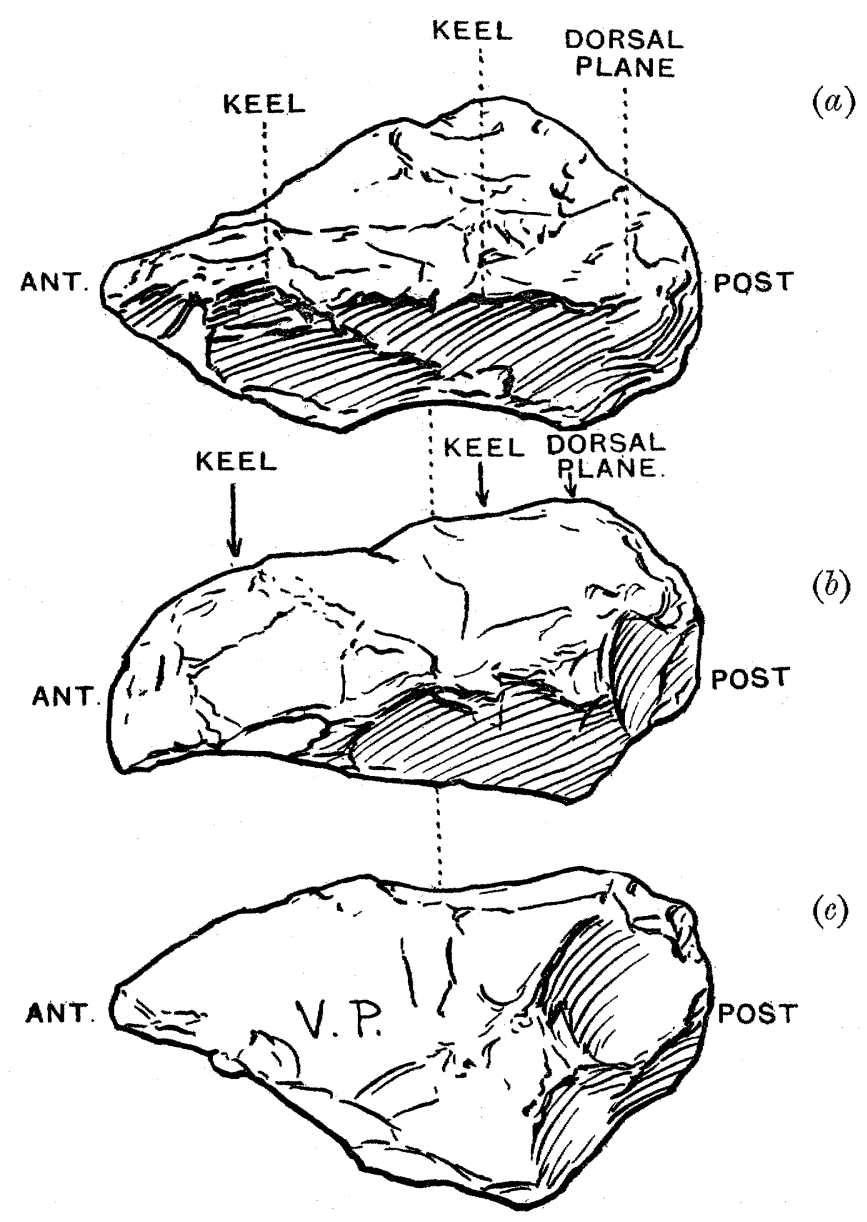

FiG. 7.-VIEW OF (a) DORSAL SURFACE; $(b)$ LEFT LATERAL SURFACE OF ROSTRO-CARINATE IMPLEMENT SHOWING FIFTH STAGE OF EVOLUTION ; $(c)$ VENTRAL SURFACE. (2 $\frac{2}{3}$ NATURAL.)

principally from specimen No. 4 (Fig. 6) in that the keel is extended farther backwards towards the posterior region with a consequent diminution of the size of the dorsal plane, also in the reduction in relative width of the ventral plane.

$$
\text { No. 6, Fig. } 8 .
$$

Found in 1893, in "Odell's Pit," Dawley, situated near West Drayton in the Thames Valley. ${ }^{1}$ The specimen was collected by the late Mr. Allen Brown, and

1 Specimens 6, 7 and 8 (Figs. 8, 9 and 10) have passed into the author's possession owing to the kindness of Dr. Allen Sturge. The author is greatly indebted to Dr. Sturge for the details supplied to him regarding the finding and provenance of these implements. 
was bought with the rest of his collection by Dr. Sturge of Icklingham Hall, Suffolk.

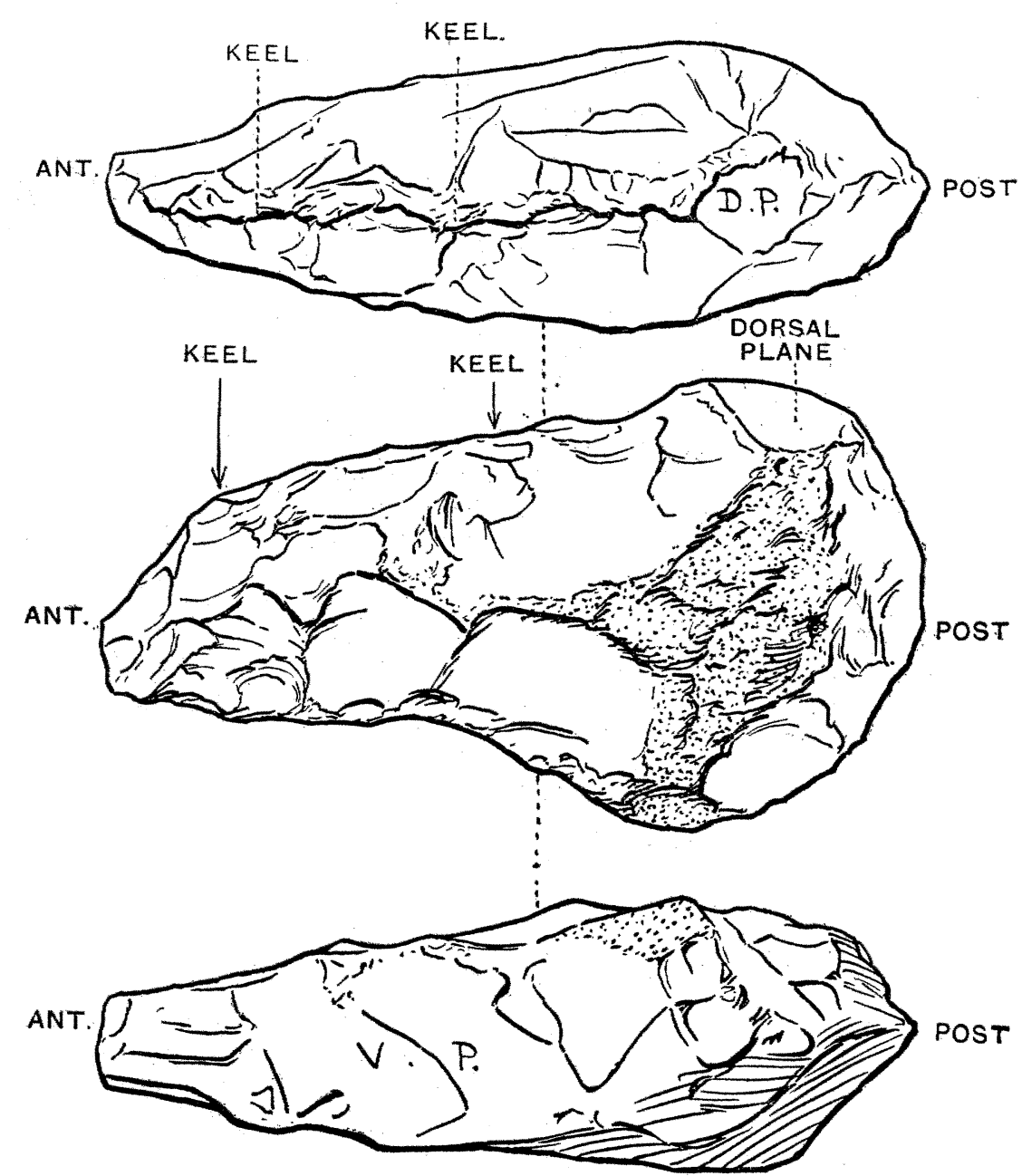

(a)

FIG. 8.-VIEW OF ( $a$ ) DORSAL SURFACE ; $(b)$ LEFT LATERAL SURFACE OF ROSTROCARINATE IMPLEMENT SHOWING SIXTH STAGE OF EVOLUTION ; $(c)$ VENTRAL SURFACE. ( $\frac{2}{3}$ NATURAL.)

The implement occurred at a depth from the surface of 21 feet, and exhibits all the characteristics of the rostro-carinate type.

The ventral plane is formed by blows, while the keel has been extended backwards towards the posterior region, with a consequent diminution of the size of the dorsal plane. The specimen shows an advance upon implement No. 5 in that it is more elaborately flaked, the keel is more extended in length, and the stern has been flaked into a rough cutting-edge. The relative width of the ventral plane as compared with No. 6 (Fig. 8) is also less. 
No. 7, Fig. 9.

Found about fifteen years ago at Warren Hill, Mildenhall, in North-west Suffolk, and acquired by Dr. Sturge from Mr. Worthington G. Smith. The specimen exhibits all the characteristics of a rostro-carinate implement. The

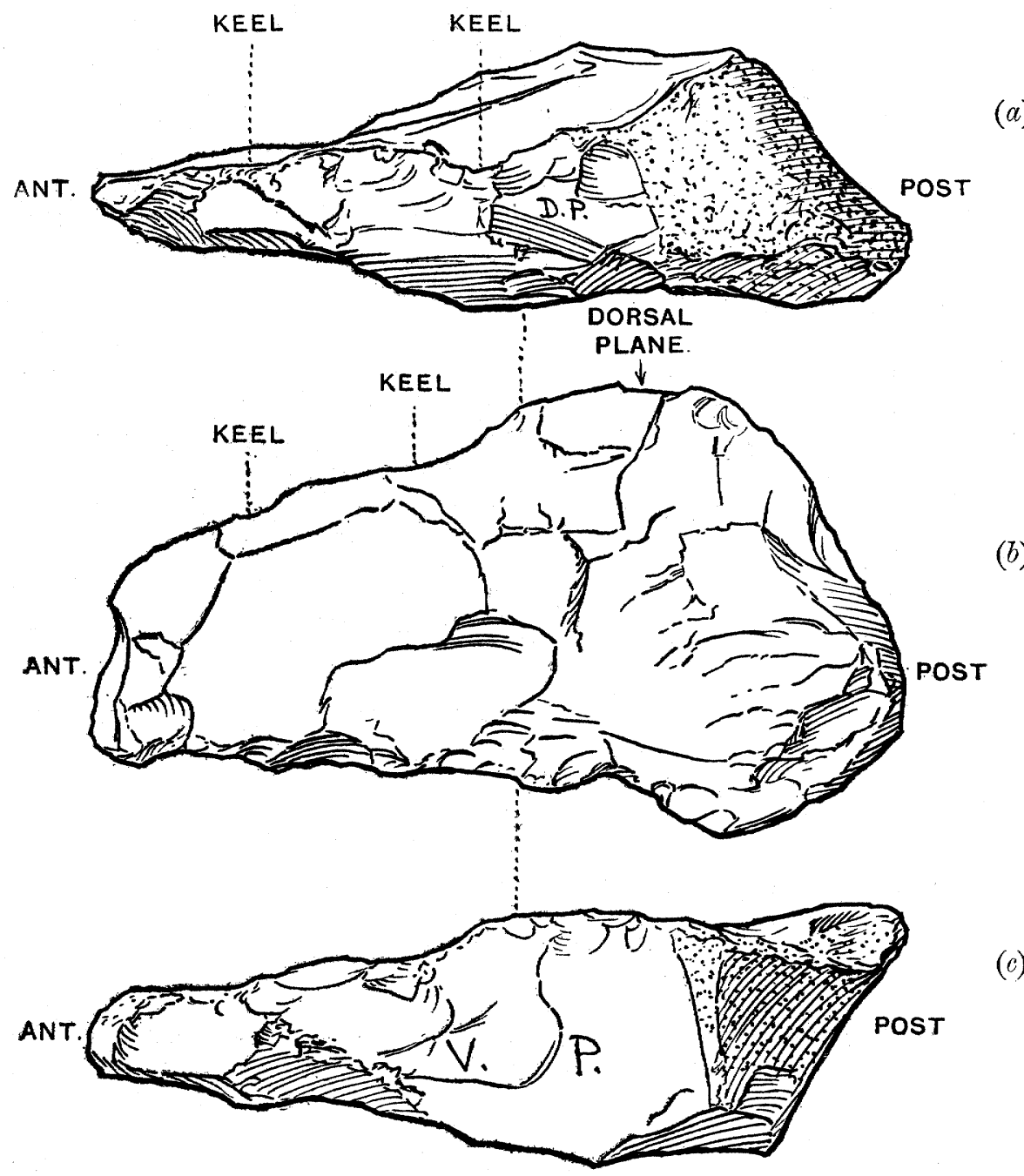

FIG. 9.-VIEW OF ( $a$ ) DORSAL SURFACE; $(b)$ LEFT IJATERAL SURFACE OF ANOTHER ROSTRO-CARINATE IMPLEMENT SHOWING SIXTH STAGE OF EVOLUTION ;

(c) VENTRAL SURFACE. ( $\frac{2}{3}$ NATURAL.)

ventral plane has been formed by blows, while the keel has been extended backwards towards the posterior region, with a consequent diminution of the size of the dorsal plane. It is regarded as representing a similar stage of evolution as specimen No. 6 (Fig. 8). 


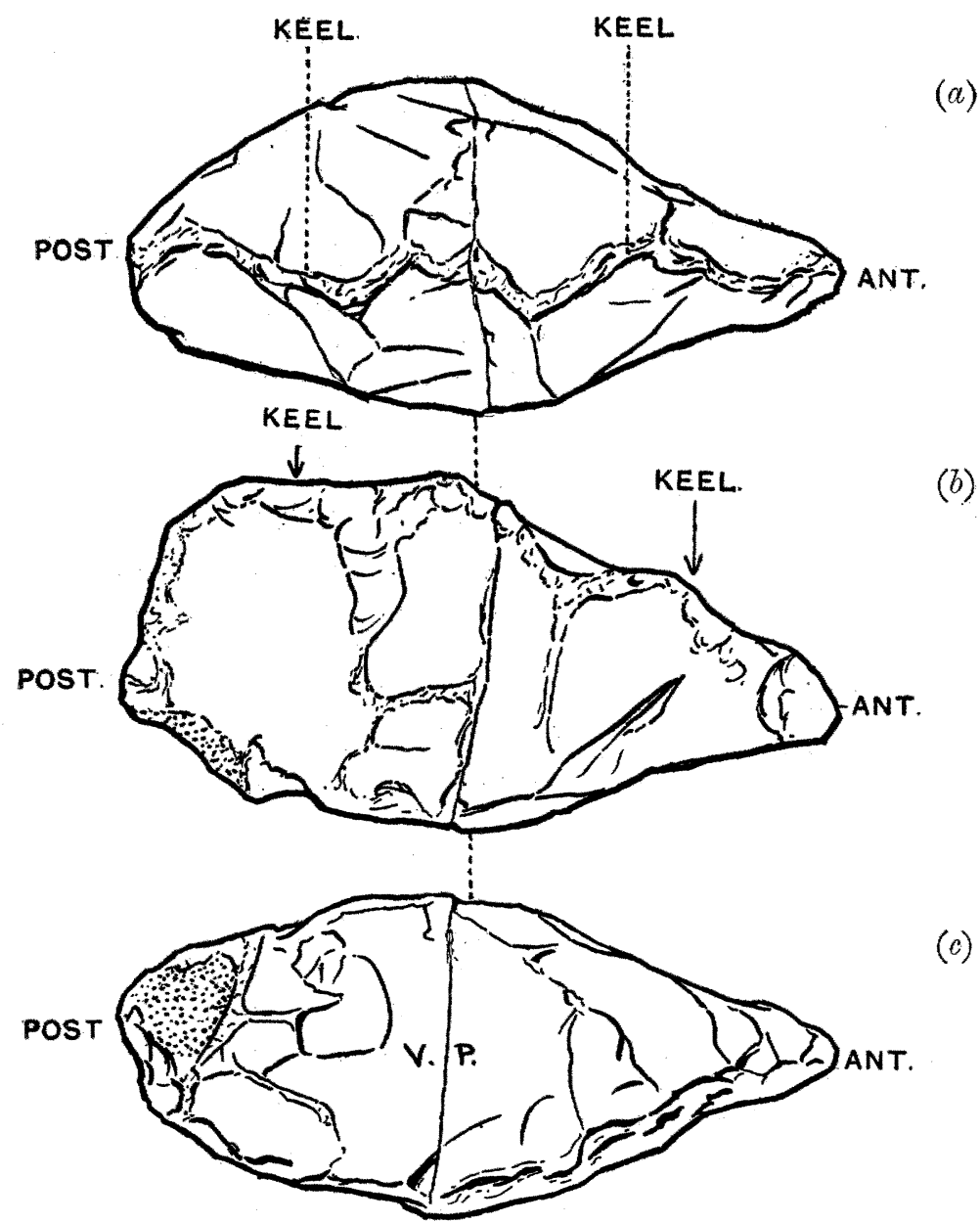

FIG. 10.-VIEW OF ( $a$ ) DORSAL SURFACE; $(b)$ RIGHT LATERAL SURFACE OF ROSTRO-CARINATE IMPLEMENT SHOWING SEVENTH STAGE OF EVOLUTION ; (c) VENTRAL SURFACE. ( $\frac{2}{3}$ NATURAL.)

\section{No. 8, Fig. 10.}

This specimen came into Dr. Sturge's collection when he purchased the collection of the late Mr. Greenhill. The implement was apparently found at Clapton in the Thames or Lea Valleys, and exhibits all the characteristics of the rostro-carinate type, except that in this case the keel has been extended backwards to the posterior region or stern, with the consequent disappearance of the dorsal plane. The relative width of the ventral plane as compared with Fig. 9 is also less.

\section{No. 9, Fig. 11.}

Found in an ancient palæolithic gravel at Ipswich. The specimen, which still retains the outline of the rostro-carinate form with the usual thickening of the 


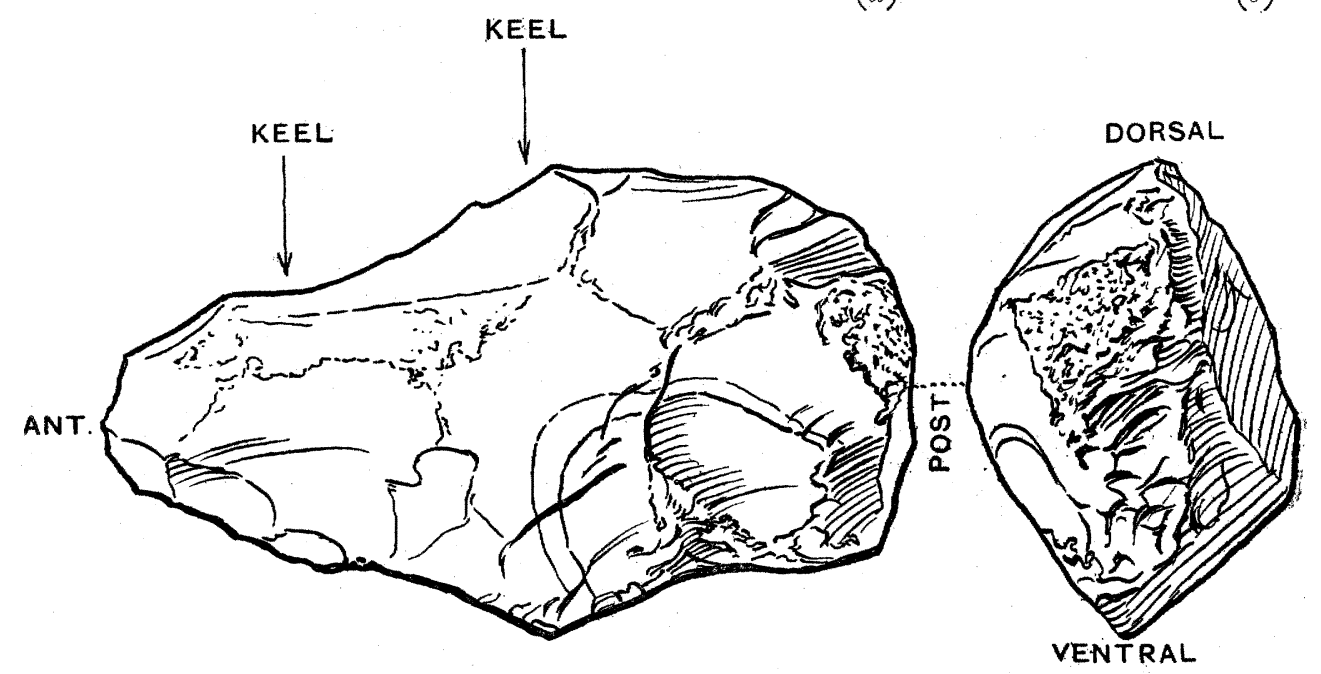

FIG. 11.-VIEW OF ( $a$ ) LEFT LATERAL SURFACE AND $(b)$ STERN (RHOMBOIDAL IN SECTION) OF EARLY CHELleS PALAOLITHIC IMPLEMENT, SHOWING FORM EVOLVED FroM ROSTROCARINATE. ( $\frac{2}{3}$ NATURAL.)

posterior region, approximates to the last-described specimen in that the keel is extended backwards to the posterior region or stern. The ventral plane, however, has been still more reduced in width and now forms a rough cutting-edge.

$$
\text { No. 10, Fig. } 12 .
$$

Found in a gravel pit at Furze Platt, near Maidenhead in the Thames valley. ${ }^{\mathrm{B}}$ The specimen, which still retains the outline of the rostro-carinate form, with the usual thickening of the posterior region (which in this case is formed almost. entirely of cortex), approximates to the last-described implement, in that the keel is extended well backwards to the posterior region.

The anterior portion of the ventral plane is so reduced in thickness as to form a cutting edge, while the posterior portion is formed of unflaked cortex. This. specimen shows an advance upon Fig. 11, in that the anterior region is much thinner, and the keel and ventral cutting-edge in consequence more acute.

The foregoing examination of these ten specimens has shown that the following fundamental changes have occurred in the making of a rostro-carinate. implement :-

(1) The substitution of a ventral plane, formed partly by blows removing flakes, for the ventral plane composed entirely of cortex such as is exhibited by the most primitive rostro-carinate specimens.

(2) The gradual elimination by flaking of cortex from the ventral plane, and the production of a flat dorsal plane formed by blows removing flakes and devoid of cortex.

1 The author is indebted to Mr. E. T. Lingwood, of Westleton, Suffolk, for permission to describe and figure this specimen. 
(3) The gradual reduction in width of the ventral plane by flaking, until a. cutting-edge is produced, and the prolongation of the ventral plane and the keel to the posterior region, accompanied by a great reduction in size, and in many cases the disappearance of the dorsal plane.

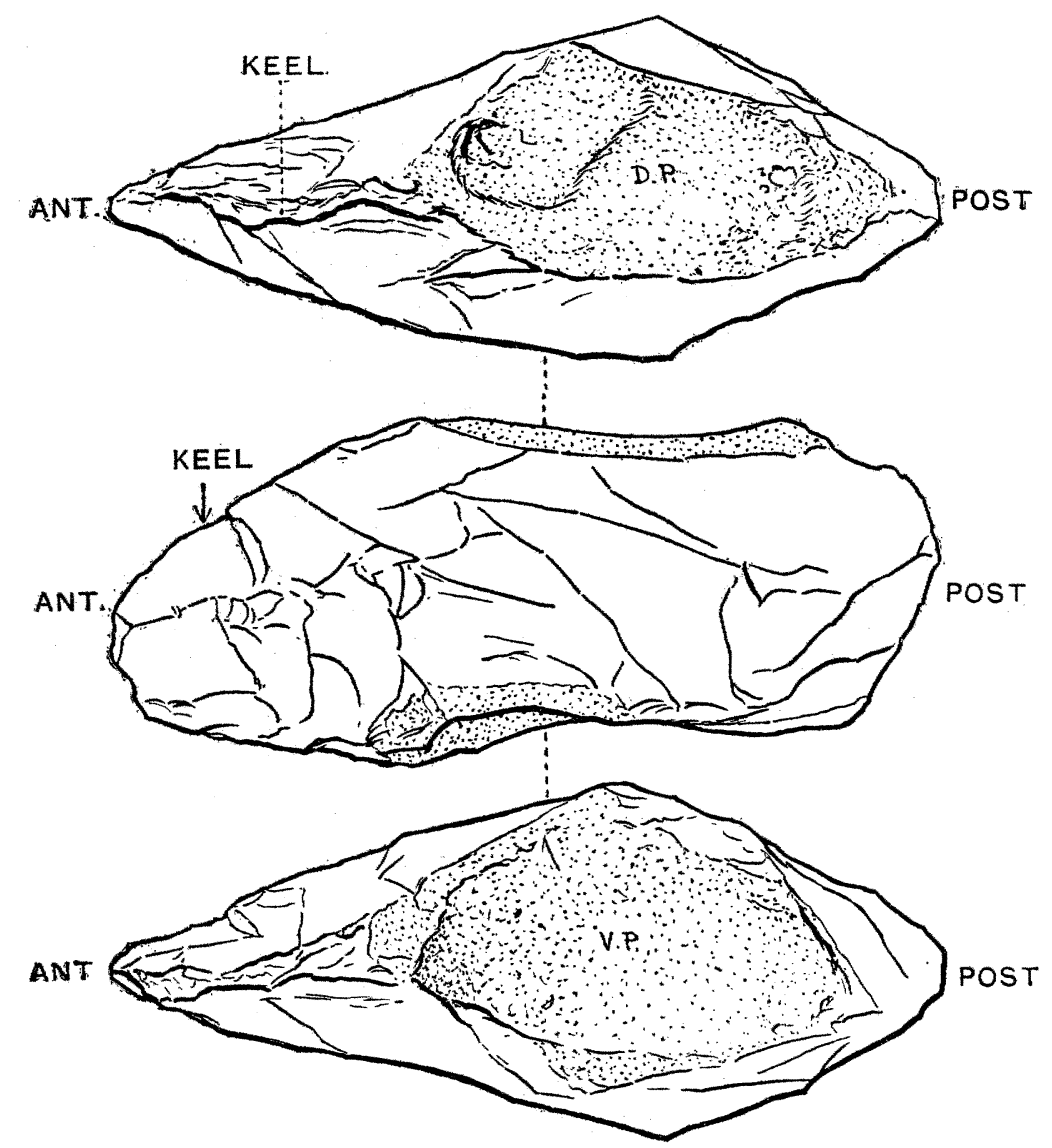

$(a)$

FIG. 12.-VIEW OF ( $a$ ) DORSAL SURFACE ; $(b)$ LEFT LATERAL SURFACE OF PAL EOLITHIC IMPLEMENT OF CHELLES TYPE SHOWING ADVANCE ON PREVIOUS FIGURE;

(c) VENTRAL SURFACE: (2 $\frac{2}{3}$ NATURAL.)

The examination has shown also, in the author's opinion, that the earliest. Chelles palæoliths of the pointed type were evolved from the rostro-carinate implements, and he now proposes to show by means of various diagrams and drawings, together with an account of some experiments in flint flaking, how, in all probability, this evolution was brought about. The section of a rostro-carinate implement is roughly a triangle and Figs. 3 to 10 exhibit such a section.

The base of the triangle is represented by the ventral plane, while the apex is represented by the keel. The ventral plane afforded the necessary flat striking surface for the removal of flakes in the formation of the keel. As this ventral plane was gradually extended backwards from the anterior to the posterior 
region, so the flat striking surface was extended, and the prolongation of the keel backwards to the posterior region (with the consequent disappearance of the dorsal plane) made possible. The section of the earliest (Chelles) palæoliths of the pointed type is roughly rhomboidal, and Fig. 11, which is of this type, shows this section.

Fig. 13 shows how the change from the triangular form of the rostro-carinate to the rhomboidal form of the earliest Chelles palæoliths of the pointed type was brought about. The two areas indicated by crosses and dotted lines were removed by flaking (principally but not entirely by blows delivered on the flat ventral surface), and the rhomboidal form of implement produced.

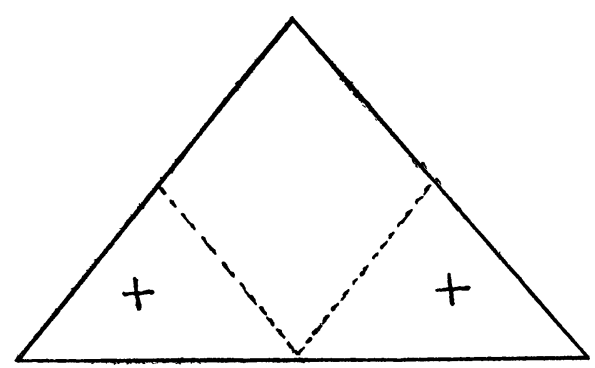

FIG. 13 .

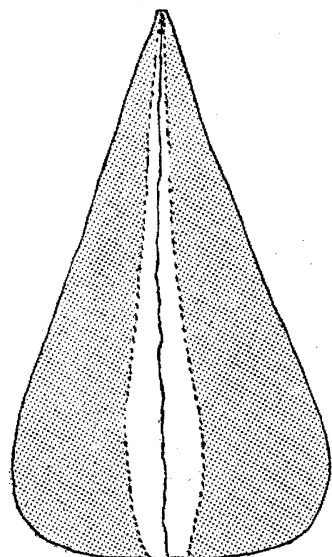

FIG. 13A.-SHOWING EDGE VIEW OF PALEOLITHIC IMPLEMENT (IN DIAGRAM) AS LEFT WHEN THE SHADED AREAS ARE FLAKED AWAY.

The author has conducted numerous experiments in flaking, and finds that the method described above is easily followed. The flint was first flaked into the form of a rostro-carinate, and then flakes were removed by means of blows delivered principally on the flat ventral plane, so as to transform this ventral plane into a rough cutting-edge, and in so doing to make an implement rhomboidal in section and approximating to the earliest Chelles palæoliths of the pointed type. ${ }^{1}$ (Fig. 13A.)

The serious attention of the reader is invited to Figs. 8, 9 and 10, which have been described.

These implements were each found many years ago in palæolithic gravel beds in the Thames Valley and at Warren Hill in Suffolk, by collectors well known in scientific circles. In the days when these specimens were found rostro-carinates

1 The transformation of the flat ventral plane into a cutting-edge necessarily brought about a change in the manner of holding the implement. The earliest Chelles specimens were no doubt grasped by the posterior region. When this posterior region, in its turn, was developed into a cutting-edge, then prehension was almost certainly given up and the implements mounted in some manner. 
were unknown, and the flints were collected as representing early palæolithic implements, and undoubted works of man. The author concludes that there is no prehistorian in any way familiar with flint implements, who would dispute the "humanity" of these particular specimens, as such non-acceptance would carry with it the rejection of all the most ancient palæolithic implements. It has been seen by the description furnished above, that without doubt these specimens (Figs. 8, 9 and 10) are of the rostro-carinate type, and it seems that all prehistorians will now agree to recognize the rostro-carinate as a distinct type of humanly-fashioned flint. implement.

These particular forms of implement, as represented by Figs. 8, 9 and 10 of the. foregoing list, have been known to prehistorians as "side-choppers," and this designation seems correct.

In each case the flat ventral plane affords a suitable flat surface for grasping, and the opposing keel a cutting-edge. The keel of Fig. 8 shows extensive evidence of its use as a.side-chopper. The realization of the use to which these rostrocarinates of the Early Palæolithic Period were put, also gives an indication of the manner in which the still earlier representatives of this type of implement were used. In the case of these latter specimeus also there seems little reason to doubt that the keel also afforded a cutting-edge, and the ventral plane the necessary flat, surface for prehension. ${ }^{1}$

It is somewhat difficult to name a use for the flat dorsal plane exhibited in Fig. 6, but this may have been used for rubbing, in the "preparation" of skins. With a view to ascertaining if further specimens of the Early Palæolithic, "side choppers" existed (other than those described in this paper), the author has examined the collections in the British Museum (Bloomsbury) and the Museum at, Ipswich, and finds that both these institutions possess such implements.

Those in the British Museum include-

2 from Shrub Hill; 1 from Aylsford; 3 from Swanscombe; 1 from Brandon; 1 from Kempston, Beds; 2 from Hill Head, Southampton; and 1 from Kent's Cavern (8-ft. level). ${ }^{2}$

\section{Ipswich Museum-}

1 each from Warren Hill, Lakenheath, Mildenhall, and Canterbury.

Dr. Sturge has also very kindly examined his large collection and states that he has "side-choppers" from West Drayton, Southall, Hanwell, Hayes, Dawley, Acton, Clapton, Hackney, Stoke Newington, Leytonstone, Wanstead, Swanscombe, and Galley Hill, in the Thames Valley. The Grindle Pit, Bury St. Edmunds;

${ }^{1}$ It may be mentioned that many of the rostro-carinates from below the Red Crag, etc., exhibit signs of having been so used.

${ }^{2}$ From drawings and photographs kindly supplied to the author by Major Marriott, D.S.O., there seems little doubt but that several of the oldest implements from Kent's Cavern approximate to the rostro-carinate type. 
Sicklesmere, near Bury St. Edmunds; Weatherhill Pit, Icklingham; Warren Hill ; High Lodge Hill Gravel; Snare Hill, Thetford. Santon Downham, Lakenheath, Brandon Fields, Shrub Hill and Methwold Warren-localities all situated in Northwest Suffolk and South-west Norfolk. Other English Gravels at Kempston, Beds; Broom Pit, Axminster; and Farnham, Surrey.

Dr. Sturge remarks that these "side-choppers" seem rarer in France than in England, as in over 100 specimens in his collection from St. Acheul there is only one, and that not quite typical. They appear to occur among the plateau specimens from Dordogne.

Examples also occur in his series from Somaliland, from the desert west of Thebes, and one specimen from "behind Table Mountain," South Africa. Dr. Sturge, to whom the author is much indebted for this very valuable information, believes that in his large series of implements from Madras these "side-choppers" occur. The author must also record a heavy palæolithic chopper in his own collection from Béthune, France, which distinctly shows the rostro-carinate form (Fig. 14).

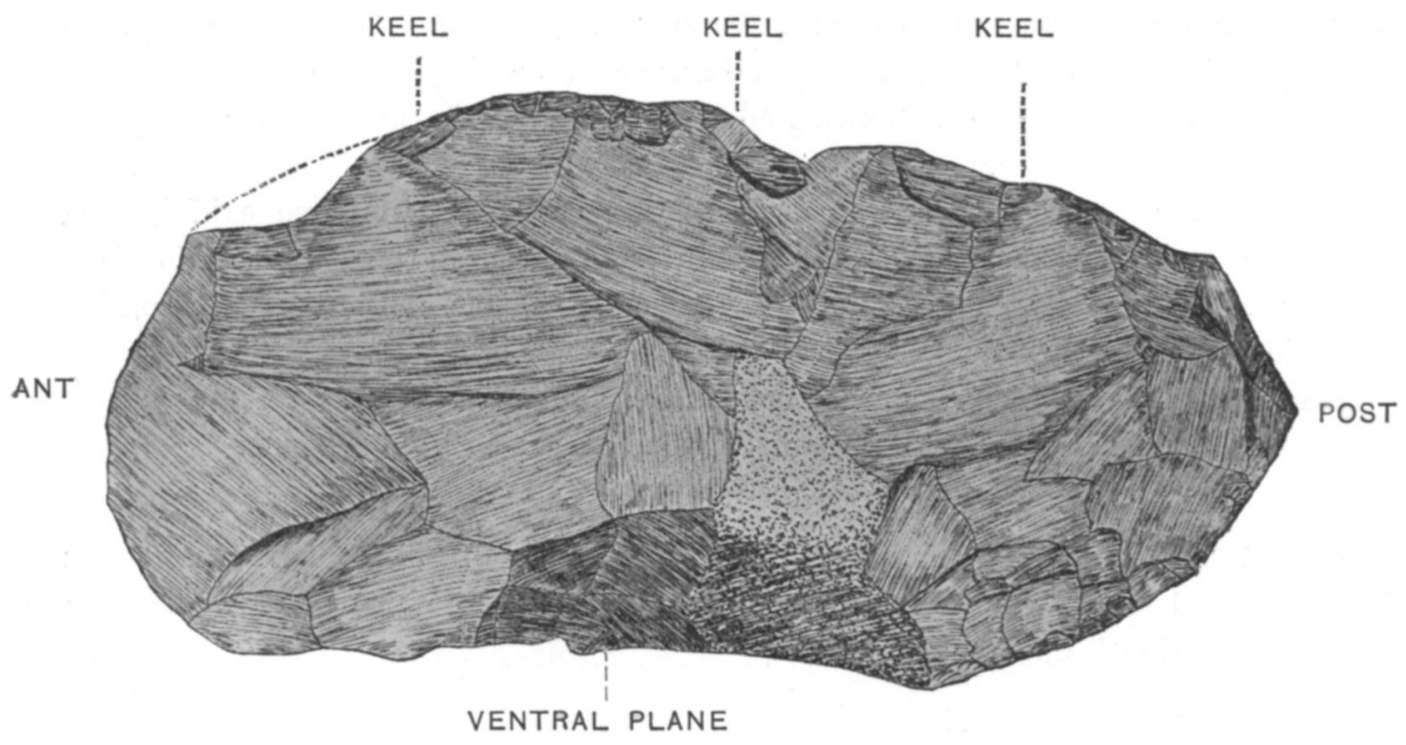

FIG. 14. (2 $\frac{2}{3}$ NATURAL.)

All the specimens examined by the author in the British Museum and the Museum at Ipswich are referable to the earliest Palæolithic Period, and Dr. Sturge writes, "As to period, they seem to be of all the gravel periods from what I believe they call pre-Chelléen, through the so-called Chelleen and onwards. I seem to have no true side-chopper from Elvedon, which is a very late "drift' period." As these "side-choppers," which the author regards as highly evolved rostro-carinate implements, are so comparatively numerous, there seems little reason to doubt that further examples will now be recognized in other collections in different parts of the country. 
It appears that the late Sir John Evans recognized the peculiar form of some of the earlier palæolithic implements of the pointed type, as on p. 554 of his Ancient Stone Implements of Great Britain, Second Edition, he figures what is without doubt a rostro-carinate implement.

The drawing which appears on the left-hand side of this page of his book clearly shows the remains of the ventral plane towards the anterior region of the implement (the ventral plane is evidently in process of being transformed into a cutting-edge in the manner which has been described earlier in this paper). The drawing on the right-hand side of the page shows the keel extending from the anterior region back to the dorsal plane, which in this case is formed of unflaked cortex.

The section of the implement is triangular, which, as has been shown, the rostro-carinate specimens, exhibit. Sir John Evans describes this specimen as follows: "The finely wrought specimens are rarer at Red Hill than at Santon Downham; but here, as elsewhere in this district, implements are occasionally found of what has been aptly termed the Shoe-shaped type, ${ }^{1}$ of which an example is shown in Fig. 429. The form is flat on one face, the other being brought to a central ridge rising towards the butt, which is usually rounded and obtusely truncated. In this specimen the greater part of the butt-end, or heel, of the shoe exhibits the original crust of the nodule of flint from which the implement was formed. The point, which is usually brought to a semi-circular edge, has been broken in old times either by use or by attrition in the gravel. Most of these shoe-shaped instruments have been formed from large spalls of flint, so that the flat face has been the result of a single blow, though occasionally retouched by subsequent chipping." (The italics are the present author's.)

The excellent drawings published by Sir John Evans and the lucid description of this Red Hill implement show, beyond any question, that it is of the rostrocarinate form.

The "one flat face" formed by "a single blow," "occasionally retouched by subsequent chipping," refers to the flat ventral plane which in some cases is being transformed into a cutting-edge by "subsequent chipping." The other face of the implement, which is "brought to a central ridge rising towards the butt," is an excellent description of the "keel" of a rostro-carinate, while the statement that " the point is usually brought to a semi-circular edge" indicates the curvature of the keel downwards to the anterior region or point of the beak of this type of implement. As has been mentioned by Sir Ray Lankester (Phil. Trans., Roy. Soc., May, 1912) Sir John Evans figures on p. 567 of his famous work (Fig. 444) a typical rostro-carinate implement found in North-west Suffolk, which he regarded as having been "designedly chipped" to fulfil some special purpose. ${ }^{2}$ The author

1 The flat sole of the "shoe" represents the flat ventral plane and the curving outline of the "toe" the keel of the rostro-carinate implement.

2 It is clear that Sir John Evans shared the author's view as to the use to which the rostro-carinate implements were put, as he states regarding the specimen figured that it has “" an oblique hatchet-like edge at the end." (Ancient Stone Implements, p. 568.) 
has in his own collection a palæolithic implement from the famous gravel-pit at. Dovercourt, Essex, which is of the true rostro-carinate type, and which, like Fig. 429 in Sir John Evans's book, shows the ventral plane partly transformed into a cutting-edge. In the Dovercourt specimen, however, it is the portion of the ventral plane towards the anterior region of the implement which has been so. transformed, while the portion towards the posterior region remains intact. (Fig. 15).

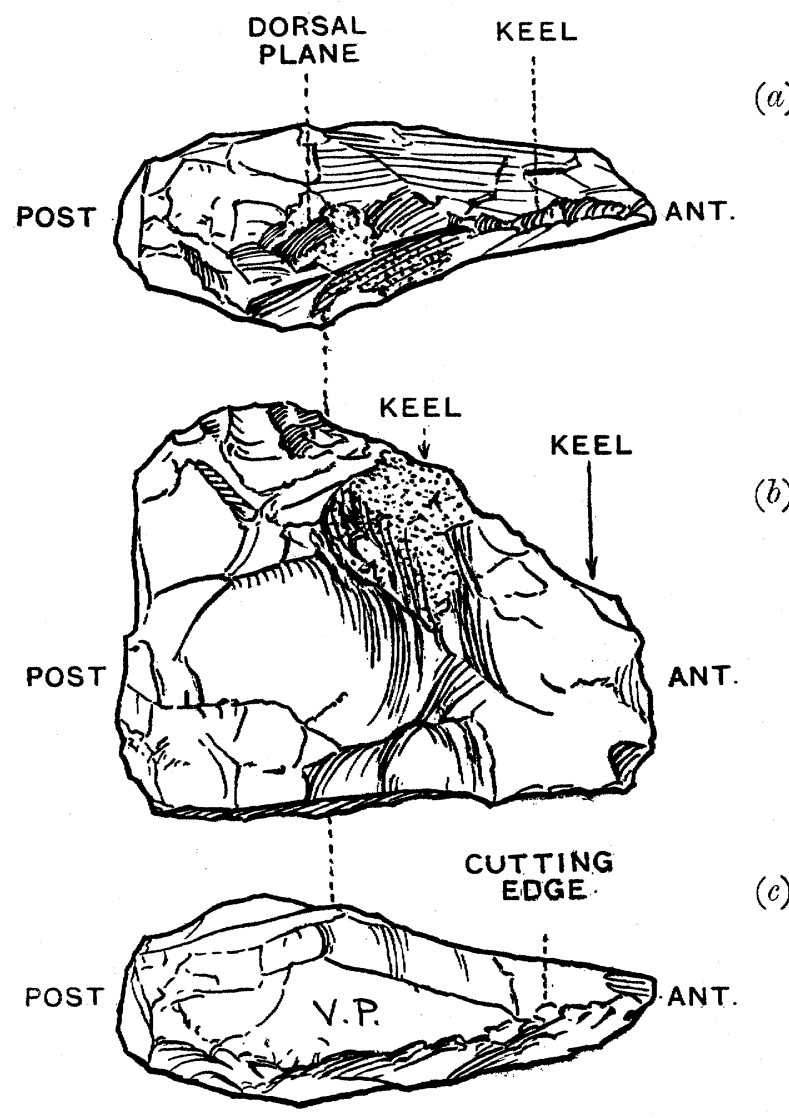

FIG. 15.-VIEW OF (a) DORSAL SURFACE : (b) RIGHT LATERAL SURFACE OF ROSTRO-CARINATE" IMPLEMENT OF PALAOLITHIC AGE FROM RIVER-TERRACE GRAVEL, DOVERCOURT, ESSEX ;

(c) VENTRAL SURFACE. (2 $\frac{2}{3}$ NATURAL.)

If the author is right in his view as to the evolution of the earliest Chelles. palæoliths of the pointed type from the rostro-carinate implements, then these latter specimens were also the parents of the St. Acheul palæoliths, which wereadmittedly evolved from the rougher Chelles type. The author considers that many of these St. Acheul specimens show, by means of what is known as the "lateral platform" which they exhibit, that they are related to the rostro-carinate implements. This "lateral platform" is a flat area evidently produced in the original "roughing out" of the implement, which occurs, almost invariably, at the 
end of one or other of the lateral edges, and nearest to the " butt-end " or posterior region of the implement. When an example of the pointed St. Acheul implement, showing a lateral platform so situated, is regarded, not in the usual manner, with the point of the specimen upwards, but with the lateral platform uppermost and the point of the implement to the left (Fig. 16), it is seen that this platform occu-

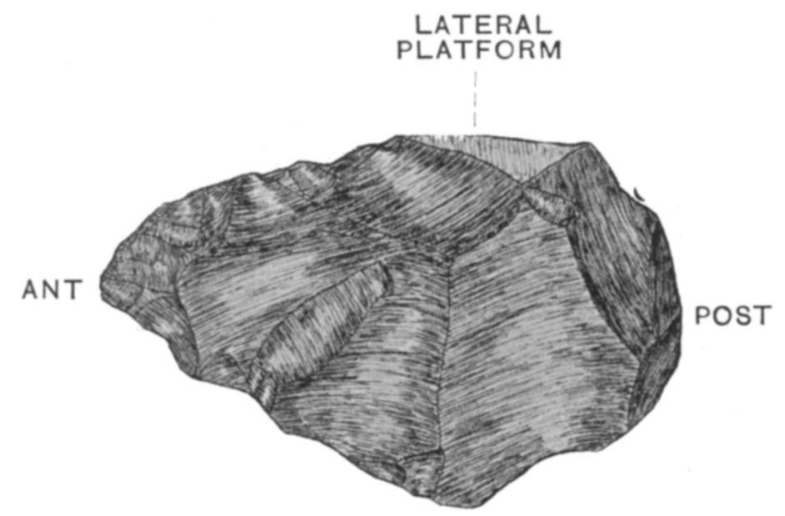

FIG. 16.-VIEW OF PALAOLITHIC IMPLEMENT FROM THAMES gravel, showing lateral platform. (2 matural.)

pies the same position as the dorsal plane of a rostro-carinate implement. It is noticeable also that many of the St. Acheul specimens of the pointed type, when regarded in the manner indicated above, show a remarkable resemblance in their profile to the profile of the rostro-carinate implements (Figs. 17 and 18).

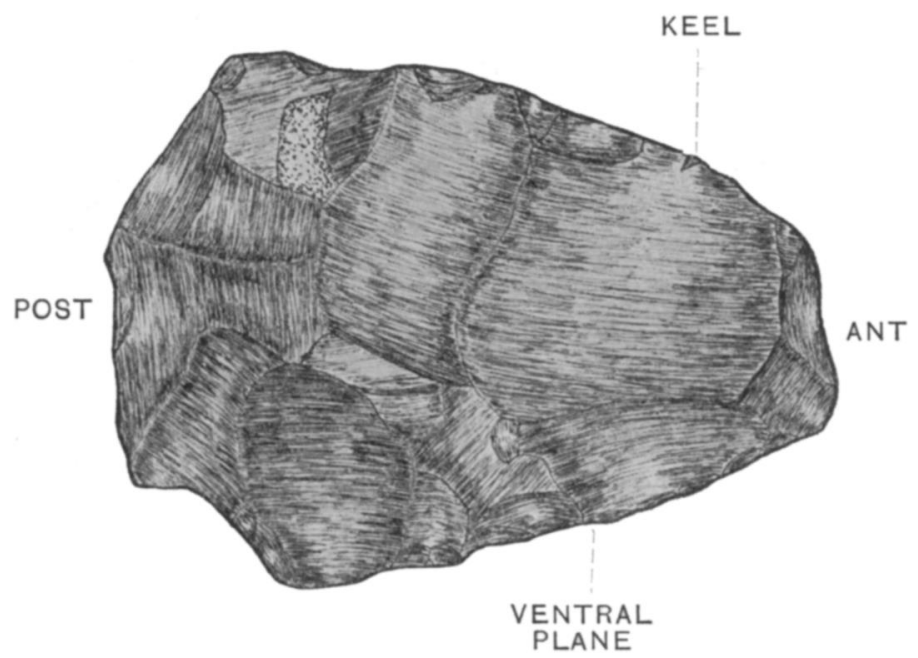

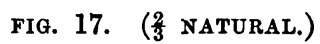

This resemblance is to be seen in the fact that one of the lateral edges of the implement curves downwards in a strongly marked manner towards the point or anterior region of the implement, while the other lateral edge forms a more or less

VOL. XLVI. 
straight line from the posterior to the anterior region. ${ }^{1}$ In the author's opinion this downward curvature of one lateral edge and the straightness of the other, as seen in so many pointed palæolithic implements of the St. Acheul type, indicate the relationship of these specimens to the rostro-carinate type.

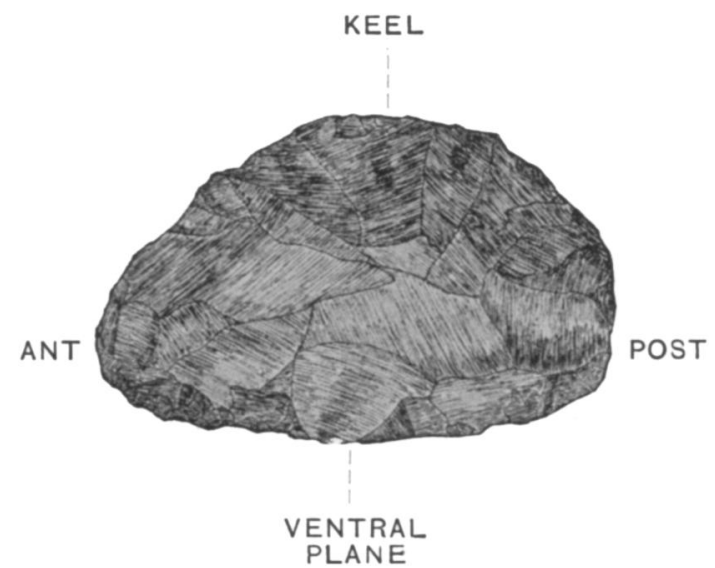

Fig. 18. ( $\frac{1}{3}$ NATURAL.)

The downward curvature of one of the lateral edges represents the keel of the rostro-carinate, which, as has been shown, also curves downward to the anterior region of the implement, while the straightness of the other lateral edge represents the straight ventral plane of the rostro-carinate form.

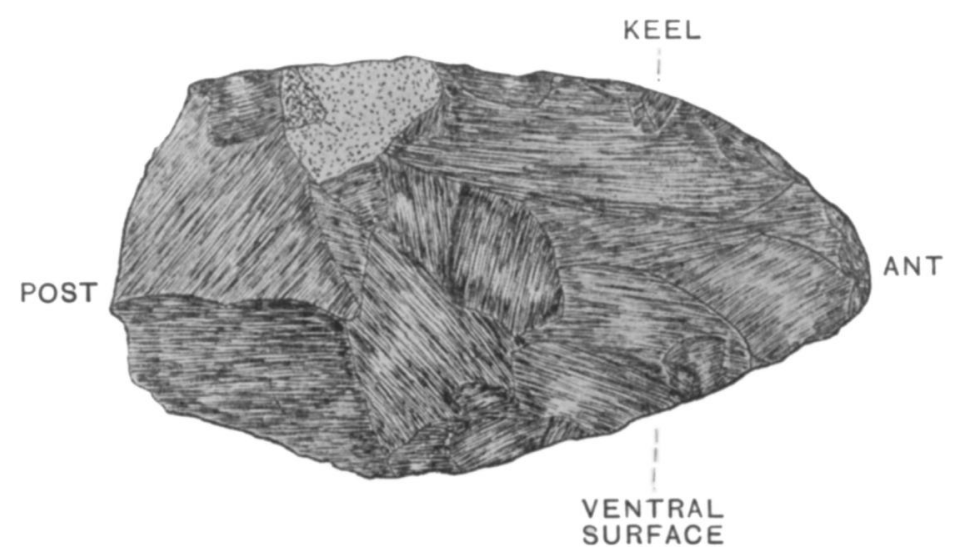

FIG. 18A. (2 NATURAL.)

(Flaked by the Author.)

1 It is suggested that in future such palæolithic implements should be regarded and figured in this aspect, so that their true significance may be recognized : the thickened "butt" end of the implement (hitherto regarded as the base) representing the posterior region and the point the anterior; the upper curved lateral edge representing the keel and the straight lateral edge the ventral region or true base of the implement. 
This same difference in the outline of the edges appears in the implements which can be produced by first of all flaking the flint into the rostro-carinate form (Fig. 18A). The reader is referred to Figs. 415, 419, 422, 429, 436, 440, 442, 447, 448, 449, 453, 457, 459, 465 and 475 of Evans's Ancient Stone Implements of Great Britain, Second Edition, for examples of the type of implement described. ${ }^{1}$

In the Museum at Ipswich there are fifteen specimens of palæolithic implements showing this peculiar asymmetry of the edges, and the author has nine in his own collection. Similar specimens probably occur in every collection of palæolithic implements, and the peculiar form of these flaked flints seems intimately related to the plan upon which the ancient flaker made his implement. The author is of the opinion that this plan consisted, first of all, in producing a rostro-carinate, and then proceeding to form a pointed palæolithic implement from it.

The author has conducted various experiments in flaking flints, and finds that the easiest way to make a palæolithic implement of the pointed type is to proceed on the rostru-carinate plan. The specimen under manufacture passes through various stages, and finally emerges as a pointed implement.

In this process the dorsal plane becomes more and more reduced in size, and finally appears as a lateral platform. A specimen flaked by the author is shown (Fig. 19), exhibiting a lateral platform, which is the remains of the dorsal plane of

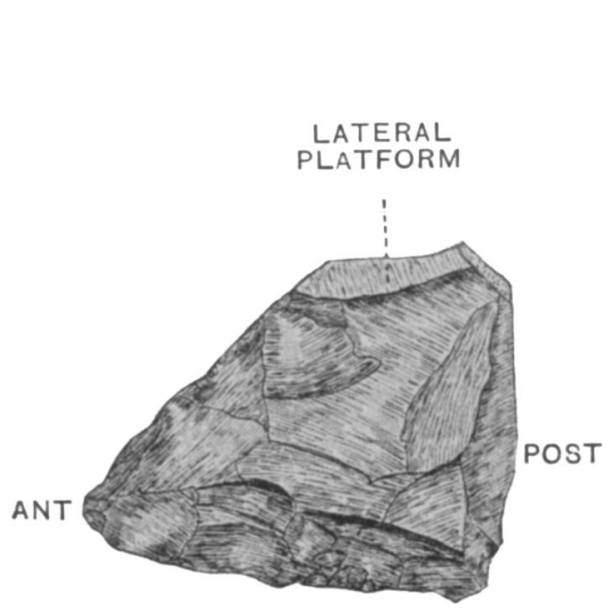

FIG. 19. (2 NATURAL.)

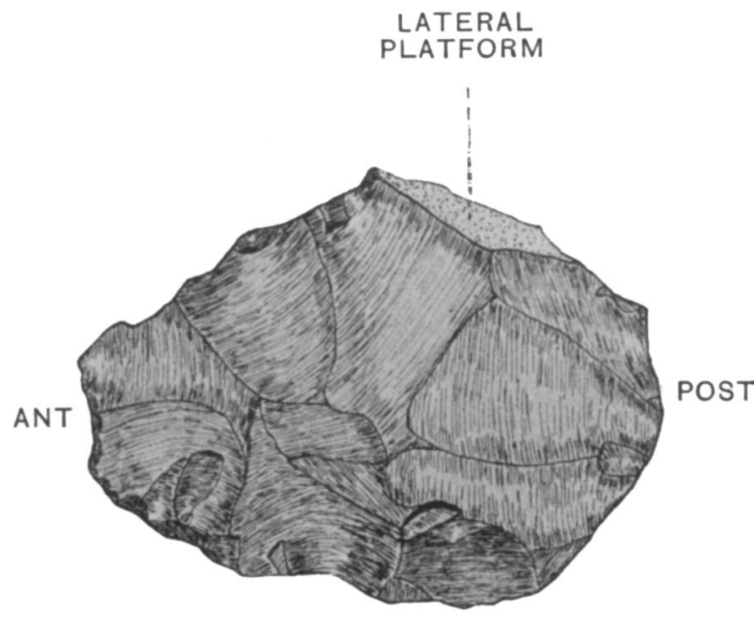

Fig. 20. (2 NATURAL.)

${ }^{1}$ It is of interest to note that Sir John Evans also recognized this peculiar asymmetry of the edges of palæolithic implements. On p. 559 of his work Ancient Stone Implements he refers to this peculiarity and states that it gives the implements a tendency to assume a "crescent-like" form: the chord of the crescent being the ventral plane and the arc the curving keel of the rostro-carinate form. 
the rostro-carinate stage, and for comparison an implement from Galley Hill, Kent, which also shows a lateral platform ${ }^{1}$ (Fig. 20).

This lateral platiorm occurs occasionally upon implements of the ovate type. If, as seems probable, the ovates were evolved from the pointed implements by the simple method of substituting the pointed end for a rounded cutting-edge, the occurrence of a lateral platform upon such specimens is easily explained (Fig. 21).

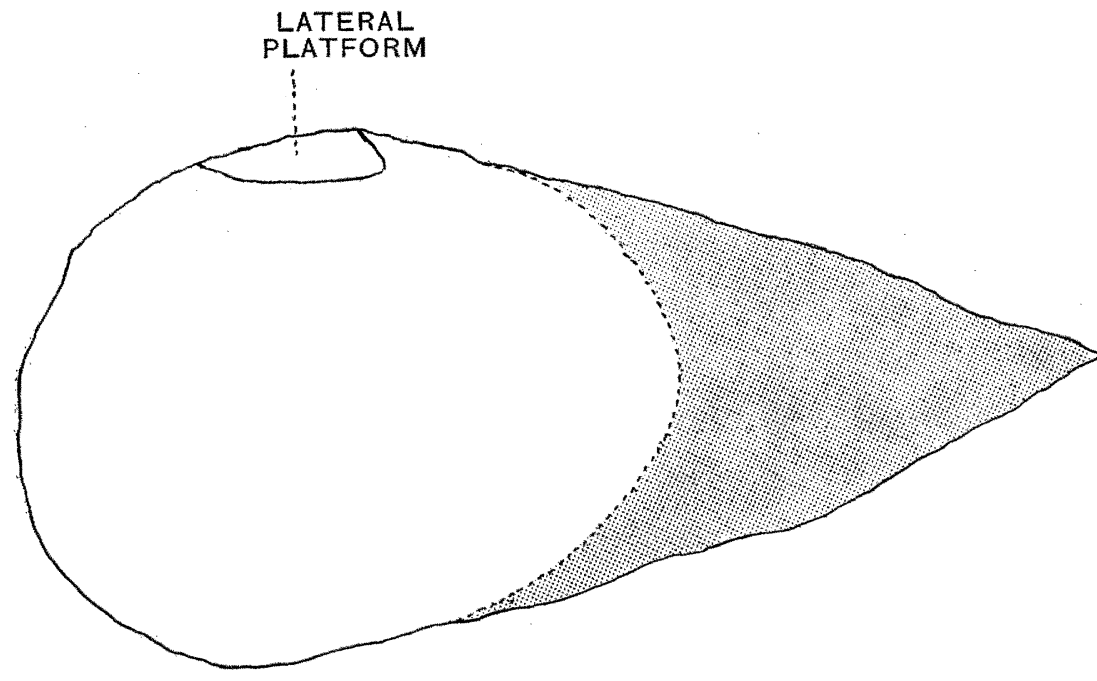

FIG. 21.-DIAGRAM SHOWING HOW OVATE IMPLEMENT MAY BE EVOLVED FROM THE POINTED TYPE BY REMOVAL OF SHADED PORTION BY FLAKING. THE LATERAL PLATFORM IS RETAINED.

The author wishes to express his gratitude to Mr. Peginald Smith for his courtesy in giving him facilities for examining a number of specimens of flint implements in the British Museum (Bloomsbury), and to Mr. Lambert for the excellent drawings which accompany this paper. Figs. 1, 2, 13, 13A, 14 to 21 were drawn by the author.

The author is also indebted to Major Marriott, D.S.O., of Lewes, for particulars regarding some of the oldest implements found in Kent's Cavern Torquay.

1 It is possible that some of these lateral platforms may be the remains of the ventral surface of the rostro-carinate form, but this can generally be determined by examining the implement in profile. 


\section{SUMMARY.}

A series of ten flint implements recovered from-

(a) The detritus-bed below the Red Crag of Suffolk,

(b) The stone-bed below the Norwich Crag,

(c) The Middle Glacial Gravel of Suffolk, and

(d) River Gravels situated in the Thames Valley and at Warren Hill in Suffolk, are described, and it is shown that the most primitive type of rostrocarinate implements from below the Red Crag of Suffolk has been evolved by gradual stages into the earliest Chelles palæoliths of the pointed type. These stages are as follows:-

(1) The substitution of a ventral plane formed partly by blows removing flakes for the ventral plane composed entirely of cortex, such as is exhibited by the most primitive rostro-carinate implement.

(2) The gradual total elimination by flaking, of cortex from the ventral plane, and the production of a flat dorsal plane by blows removing flakes and devoid of cortex.

(3) The gradual reduction in width of the ventral plane by flaking until a cutting-edge is produced, and the prolongation of the keel to the posterior region, accompanied by a great reduction in size, and, in many cases, the disappearance of the dorsal platform.

Three of the flint implements described were found many years ago, before rostro-carinates were known, in the Thames Valley and at Warren Hill in Suffolk. These specimens were collected as palæolithic "side-choppers," but it is evident they are rostro-carinate implements. Numerous other specimens of such palæolithic "side-choppers" from various parts of the world are mentioned. As there can be no doubt as to the "humanity" of these palæolithic specimens, it should now be admitted by all prehistorians that the rostro-carinate is a definite type of humanly-fashioned flint. It is pointed out that if the earliest Chelles palæoliths of the pointed type are related to the rostro-carinate implement, then the later St. Acheul implements which were admittedly evolved from the Chelles specimen, must also be related to the rostro-carinates. This relationship is, in the opinion of the author, shown in the presence of a "lateral platform" on so many of the St. Acheul implements. This lateral platform is in all probability the remains of the dorsal plane of the rostro-carinate.

Many of the St. Acheul implements, in their profile, also show their relationship to the rostro-carinate implements.

The author has conducted various experiments in flaking flints, and finds that the easiest way to make an implement of the pointed type is to proceed as if it were desired to make one of the rostro-carinate form. He has found that the 
remains of the dorsal plane appear as a lateral platform on the specimens he has made, and that the outline of the rostro-carinate is sometimes preserved. Lateral platforms appear on ovate implements, but as these were in all probability evolved from specimens of the pointed type, by the simple method of substituting a rounded cutting-edge for the pointed end, the occurrence of such lateral platforms upon these specimens is easily explained. 